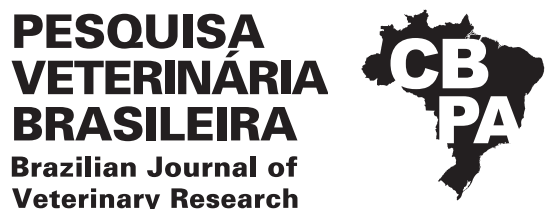

\title{
Research and extension action for parasitic control in pig breeding families located in Tanguá, Rio de Janeiro ${ }^{1}$
}

\author{
Camila S.C. Class' ${ }^{2}$, Renato L. Silveira ${ }^{3}$, João Pedro S. Palmer ${ }^{2}$, Priscila A. Fialho², \\ Lucas F. Lobão², Laís V. Dib² ${ }^{2}$ Claudia Maria A. Uchôa ${ }^{2}$ and Alynne S. Barbosa ${ }^{2,4 *}$ (D)
}

\begin{abstract}
Class C.S.C., Silveira R.L., Palmer J.P.S., Fialho P.A., Lobão L.F., Dib L.V., Uchôa C.M.A. \& Barbosa A.S. 2020. Research and extension action for parasitic control in pig breeding families located in Tanguá, Rio de Janeiro. Pesquisa Veterinária Brasileira 40(10):739-749. Laboratório de Bioagentes Ambientais, Departamento de Microbiologia e Parasitologia, Instituto Biomédico, Universidade Federal Fluminense, Niterói, RJ 24210-130, Brazil. E-mail: alynnedsb@gmail.com

This study aimed to analyze the parasites infesting pigs and their producers on family farms in Tanguá, RJ, Brazil, and to conduct extension activities between 2018 and 2019. Fecal samples were collected from 132 pigs, as well as, skin scrapings from the ears of 125 animals. In addition, 36 stool specimens from farmers and their families were analyzed. The collected material was processed by direct examination, sedimentation and flotation techniques. Gastrointestinal parasites were detected in $88.6 \%$ of the pigs, especially coccidia (71.8\%), Balantioides coli (55\%), strongyles (40.2\%) and Strongyloides ransomi (31.6\%) which showed statistically significance $(\mathrm{p}<0.05)$. Ectoparasites were identified in $16 \%$ of the pigs, mostly Sarcoptes scabiei var. suis $(76.2 \%)$. Parasites were detected in $19.4 \%$ of the humans, including, Entamoeba coli (19.4\%), Ascaris lumbricoides (8.3\%) and Trichuris trichiura $(5.5 \%)$. The frequency of B. coli and S. scabiei var. suis $(\mathrm{p}<0.05)$ were statistically significant, when analyzing the age group-of the animals, having been more detected in the older years, fatterners phase. The pig farmers participated in these activities extension, which included lecture and "field day", aimed at imparting information about parasites and their prophylaxis. The situation in Tanguá pig farms reinforces the need to carry out programs that provide technical support to these farmers, whose livelihood depends on pig farming.
\end{abstract}

INDEX TERMS: Parasitic control, pig breeding, Rio de Janeiro, pigs, gastrointestinal parasites, scabies, rural extension.

RESUMO.- [Pesquisa e ação de extensão para controle das parasitoses em propriedades familiares de criação de suínos localizadas em Tanguá, Rio de Janeiro.] Este estudo objetivou analisar os parasitos que infectam suínos e seus produtores em propriedades familiares em Tanguá, RJ, Brasil, realizando atividades extensionistas entre 2018 e 2019. Amostras fecais foram coletadas de 132 suínos,

\footnotetext{
${ }^{1}$ Received on May 9, 2020.

Accepted for publication on July 11, 2020.

${ }^{2}$ Laboratório de Bioagentes Ambientais, Departamento de Microbiologia e Parasitologia, Instituto Biomédico, Universidade Federal Fluminense (UFF), Rua Professor Hernani Melo, 101, Niterói, RJ 24210-130, Brazil.

${ }^{3}$ Departamento de Morfologia, Instituto Biomédico, Universidade Federal Fluminense (UFF), Rua Professor Hernani Melo 101, Niterói, RJ 24210-130, Brazil.

${ }^{4}$ Laboratório de Toxoplasmose e Outras Protozooses, Fundação Oswaldo Cruz (Fiocruz), Rio de Janeiro, RJ 21040-360, Brazil. *Corresponding author: alynnedsb@gmail.com
}

bem como raspados da pele da orelha de 125 animais. Além disso, 36 amostras fecais dos produtores e seus familiares foram analisadas. 0 material coletado foi processado pelo exame direto e por técnicas de sedimentação e flutuação. Parasitos gastrointestinais foram detectados em $88,6 \%$ dos suínos, principalmente coccídios (71,8\%), Balantioides coli $(55 \%)$, estrôngilos $(40,2 \%)$ e Strongyloides ransomi $(31,6 \%)$ que apresentaram significância estatística $(\mathrm{p}<0,05)$. Ectoparasitos foram identificados em $16 \%$ dos suínos, principalmente Sarcoptes scabiei var. suis (76,2\%). Parasitos foram detectados em 19,4\% das amostras fecais humanas, incluindo Entamoeba coli $(19,4 \%)$, Ascaris lumbricoides $(8,3 \%)$ e Trichuris trichiura (5,5\%). A frequência de B. coli e S. scabiei var. suis foi estatisticamente significativa $(\mathrm{p}<0,05)$, quando se analisou os animais por faixa etária, tendo sido principalmente detectado nos animais mais velhos; como na fase de terminação. Os produtores de suínos participaram 
ativamente das atividades de extensão, incluído a palestra e a atividade "dia de campo", que tinham como objetivo mediar informações sobre parasitos e suas medidas profiláticas. A situação nas granjas familiares de Tanguá demonstra a necessidade de realização de programas que apoiem tecnicamente esses produtores, que utilizam a suinocultura como fonte de subsistência.

TERMOS DE INDEXAÇÃO: Controle de parasitoses, criação de suínos, Rio de Janeiro, suínos, parasitos gastrointestinais, sarna, extensão rural.

\section{INTRODUCTION}

Brazil stands out worldwide in pig farming, mainly in industrial animal agriculture, where pigs are raised in total confinement in intensive systems under highly sanitary conditions. Today, research and investments in pig farming have placed Brazil in fourth place in the ranking of the world largest pork producers and exporters (Embrapa 2018).

Notwithstanding the excellence of industrial farming in Brazil, a large part of pig production is concentrated on small farms, which generally raise these animals as a source of primary or secondary income and/or of subsistence. Generally, this type of pig farming involves simple intensive or extensive systems, with little financial and technological investment. This activity takes place at approximately $46.5 \%$ of the 5.8 million farms in Brazil, which typically employ family labor and constitute an important source of income (Silva Filha et al. 2011).

In national pig herds, health problems can be attributed to a variety of biological agents, including gastrointestinal parasites and ectoparasites, which are one of the limiting factors in raising these animals (Carreiro et al. 2016). The main negative effects of parasitic diseases in pigs are economic losses for producers, such as reduced feed conversion, reduced fertility, low number of piglets born and weaned, low weight at birth and at weaning, in addition to losses resulting from high discard rates in slaughterhouses (Roepstorff et al. 1998, Nansen \& Roepstorff 1999, Barbosa et al. 2015a). Moreover, pigs are considered the main reservoirs of Balantioides coli, Entamoeba polecki and also Blastocystis sp. a protozoan with zoonotic potential that can infect humans, especially farmers that raise these animals (Solaymani-Mohammadi \& Petri Jr 2006).

Not only endoparasites but also arthropods represent a major problem in pig farming, especially Sarcoptes scabiei variety suis, which is considered the most important ectoparasitic mite in pig farming. In pigs, this ectoparasite can cause sarcoptic mange, i.e., scabies, manifested in the form of intense itching, causing extreme discomfort and favoring infestation by other secondary pathogenic organisms. Thus, scabies can cause economic losses for the producer through reduced growth rates of the animals, low reproductive efficiency, and increased carcass disposal rates in slaughterhouses (Sobestiansky et al. 2005).

The national scientific literature contains several studies analyzing pig parasites recovered from fecal samples, especially studies conducted on family farms. These studies have reported high positivity rates for gastrointestinal parasites, i.e., about $90 \%$ of pigs raised on family farms in the states of Sergipe, Bahia, Distrito Federal and Rio de Janeiro (Pinto et al. 2007, Aguiar 2009, Brito et al. 2012, Barbosa et al. 2015a). With regard to ectoparasites, all the studies conducted in Brazil focused on industrial farms, but none of them involved family farms. In the biological samples collected from pigs on industrial farms, positivity for Sarcoptes scabiei variety suis was reported, ranging from $0.09 \%$ to $16.6 \%$ in biological samples collected from pigs raised on farms in southern Brazil and $12.1 \%$ and $43.5 \%$ on farms in the north (Silva et al. 2002, Pedroso-de-Paiva et al. 2003, Sobestiansky et al. 2005, Oliveira et al. 2006).

In view of the above, it is important to carry out studies on family pig farms to ascertain the parasite infection rates among these animals and their producers, and to conduct qualitative research to learn about these farmers' conditions of management and socioeconomic health, associating them with extension activities aimed at mediating information about parasites. It should be noted that studies on this topic have not yet been carried out in Brazil. In the state of Rio de Janeiro, these small family farmers are concentrated in the interior of the state, as is the case of the Tanguá city and neighboring cities, which still have areas with little urbanization. Thus, this study aimed to analyze the frequency of parasites detected in pigs, relating their positivity rates to the sex and age of the animals, and to perform the same analysis on human fecal samples from pig farmers on family farms, associating the information garnered in this research with extension activities.

\section{MATERIALS AND METHODS}

\section{Ethical consideration}

This study was approved by the Ethics Committee on Animal Use of the Universidade Federal Fluminense (CEUA/UFF) under Protocol no. 1048, and by the Human Research Ethics Committee of UFF under Protocol no. 2686336.

\section{Study location}

This study was carried out from June 2018 to August 2019 on family owned pig farms located in Tanguá city $\left(22^{\circ} 43^{\prime} 48^{\prime \prime} \mathrm{S}\right.$, $42^{\circ} 42^{\prime} 50^{\prime \prime} \mathrm{W}$ ), which covers an area of $146.62 \mathrm{~km}^{2}$, with tropical climate and is part of the metropolitan region of the state of Rio de Janeiro. Tanguá is surrounded by Itaboraí, Maricá, Rio Bonito and Saquarema cities. Tanguá consists of 10 neighborhoods, has a population of about 30,732 , is rich in natural resources, and has small farms run by nuclear families (Brasil 2015) (Fig.1).

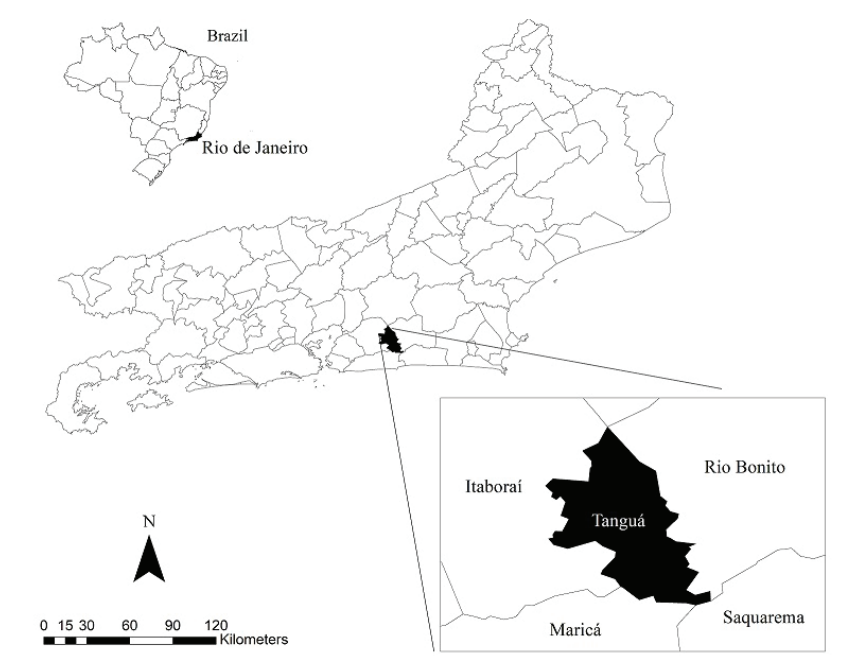

Fig.1. Location of Tanguá city in the state of Rio de Janeiro, Brazil. 


\section{Study design, application of forms and collection of biological samples}

This study involved seven technical visits to each farm for a variety of objectives. The visits occurred at intervals of approximately 10 days. During the period of this study, a leaflet was delivered to the neighborhood community outpatient health clinic to inform the local doctor about the study, in case anyone included in it sought medical treatment.

First visit. Consisted of presenting the study in a simple conversation with farm owners and other family members and obtaining their signature on the informed consent forms required by the Ethics Committees. Since the city does not have a register of these small family farms, they were identified based on information provided by other farmers living in the city. The farmers who agreed to participate in the study filled out two semi-structured forms, one containing questions about the pigs and pig-raising management, which was answered only by the producer, and the other, which was answered individually by each family member, and included sanitation-related questions. After the forms were filled out, the research team walked around the farm in order to familiarize themselves with the property and the pig raising operation.

Second visit. Fecal samples from these animals were collected directly from the rectal ampulla using a rectal palpation glove lubricated with glycerin, and were duly tagged. Material from the outer ears was collected using a stainless steel spatula soaked in glycerin and was deposited in sterile plastic Petri dishes, which were then tagged and sealed with tape. Piglets younger than one month and pregnant sows were not included in the sampling procedures. In addition, during this visit, stool collection kits were delivered to farmers and their family members for their own use. These kits contained two labeled $80 \mathrm{~mL}$ stool specimen containers without chemical preservative, two wooden spatulas and a leaflet describing the proper collection procedure. Each person was also told that the samples should be collected on two different days and stored in a refrigerator door. The stool samples from each person were picked up by the study team at a prearranged time.

Third visit. Included the delivery of the parasitology test results of humans and pigs. The test results of the pigs were explained to each farmer, while the human test results were explained individually to clear up any doubts. At the end of this visit, a presentation called "Parasites and the importance of their control" was made on a structure resembling a large book made of canvas posters. Most of the information in this material was visual with figures.

Fourth visit. Consisted of a "field day," accompanying the farmer in his daily routine activities of cleaning pig pens and sanitizing the animal feed and water troughs. During this visit, the team members held discussions with the farmers about the correct and incorrect animal handling procedures they had adopted and suggested steps to correct them. Also during this visit, antiparasitic drugs containing fenbendazole as active ingredient were mixed into the pig feed. At the end of this visit, the producer was given two posters. One of them was entitled "Ten important steps for the producer: hygiene in pig farming," which repeated the information about good pig raising practices. The other poster was a "Health Calendar," whose purpose was schedule medications and to remind them of the dates and drugs given to their pigs. The two posters were posted on the farm at specific locations selected jointly by the farmers and researchers.

Fifth, sixth and seventh visits. These visits involved an activity called "homework checking," to determine whether the animal handling information and advice was being carried out on the farm. These visits also provided opportunities for questions to be asked and doubts cleared up about the subjects previously discussed.

\section{Laboratory processing of fecal samples and skin scrapes from the ear}

A part of the human and pig fecal samples was immediately processed by direct examination. Another part of the sample was homogenized and the filtrate was aliquoted and placed in $15 \mathrm{ml}$ conical bottom centrifuge tubes and processed by the centrifugal sedimentation method proposed by Ritchie (1948) modified by Young et al. (1979), to the centrifugal flotation technique of Faust et al. (1938); and to the centrifugal flotation method of Sheather (1923) modified by Huber et al. (2003). Part of the filtered material was allowed to settle for 24 hours in conical bottom flasks to perform the spontaneous sedimentation technique (Lutz 1919).

In the Parasitology laboratory, the samples collected from the pigs' ear pavilion were submitted to the protocol described by Ferreira (2010) with some modifications. The Petri dishes containing the samples collected from the ear were incubated at $30^{\circ} \mathrm{C}$ in a bacteriological incubator for $30 \mathrm{~min}$, and then examined in an Olympus ${ }^{\circledR}$ CKX41 inverted microscope under 100x magnification. The Petri dishes were then covered with a lactophenol solution, sealed again, and incubated at room temperature for one month. After this period, the samples were transferred to $15 \mathrm{ml}$ centrifuge tubes, with $1 \mathrm{ml}$ of sediment in each tube, which were completed with distilled water to a volume of $15 \mathrm{ml}$, and then centrifuged at $2500 \mathrm{rpm}$ for five min. After centrifugation, a microscope slide of the tube sediment was prepared, covered with a $24 \times 32 \mathrm{~mm}$ coverslip, and examined under an optical microscope.

After examining the slide, the remaining pellet in the tube was suspended with sucrose solution at a density of $1,300 \mathrm{~g} / \mathrm{ml}$ until a volume of $15 \mathrm{~mL}$. This solution was then centrifuged at $1500 \mathrm{rpm}$ for $10 \mathrm{~min}$. After this procedure, the tubes were placed on shelves and the sucrose solution was added until a meniscus was formed over which were placed $24 \times 32 \mathrm{~mm}$ coverslips, which were left to rest on the meniscus for $20 \mathrm{~min}$ in this flotation stage.

An Olympus BX 41 optical microscope was used to examine the slides obtained in each technique, initially under 50x and $100 \mathrm{x}$ magnification, and then under 400x for confirmation, when necessary. An ocular micrometer was used for morphometry of evolutionary forms of the identified parasites.

\section{Data analysis}

All the qualitative information retrieved from the forms was tabulated and presented descriptively, by means of a percentage, while the most widely reported information was presented in tables. Data on the animals' sex and age, in months, were also retrieved and tabulated. Thus, the pigs were classified in stages, as follows: Initial stage - from one to two months of age to weaners, Growing stage - from two to four months old, and Fattening stage - four months and older.

A biological material was considered positive when at least one parasite was found (trophozoites, eggs, larvae, cysts or oocysts). The frequency was determined by dividing the number of positive samples by the total number of samples collected, and these data were presented in percentages. Fisher's exact test with a 5\% confidence level was applied, using Graph Pad version 6 software, to analyze the parasite positivity rate according to the taxonomic classification of parasites and also to the categories of age and sex of the pigs.

\section{RESULTS}

This study involved a total of 14 family farms, which were identified by the letters A to $\mathrm{N}$. The number of pigs on these farms varied 1 to 56 . Of the 132 pigs included in this study, $88.6 \%$ of them had gastrointestinal parasites, with protozoa 
detected more than helminths. In fact, the parasite positivity rate among the animals on these farms exceeded $70 \%$. In general, non-sporulated coccidia oocysts were the most frequently detected parasites, followed by Balantioides coli, strongyles and Strongyloides ransomi, whose presence was statistically significant $(\mathrm{p}<0.05)$. Other parasites were also detected, such as amoebic cysts, eggs of Trichuris suis and Ascaris suum, cysts of Blastocystis spp. and eggs of Capillaria spp. However, the frequency of these parasites was not statistically significant ( $p>0.05$ ). Among the 125 biological samples collected from the pigs' ears, forms similar to ectoparasites were diagnosed in $20(16 \%)$ samples, and adult forms of the mite Sarcoptes scabiei variety suis was the most frequently detected, showing a statistically significant frequency $(\mathrm{p}<0.05)$ (Table 1$)$.

Of the 132 pigs included in the study, 62 were females and 70 were males, with $90.3 \%$ and $87.1 \%$, respectively, testing positive for parasites. Protozoa and helminths were detected in the feces of both females and males. However, no significant statistical relevance was found in the diagnosis of parasite taxa when the frequency was compared as a function of sex ( $p>0.05)$. As for age groups, the older pigs, i.e., those in the fattening stage, showed a higher positivity rate than the other age groups. B. coli and S. scabiei var. suis were the parasites that showed a significant difference in a comparison of frequency rates as a function of age groups $(\mathrm{p}<0.05)$ (Table 2$)$.

Based on information obtained from the forms answered by the farmers about their pig management procedures and on the observations of team members, it can be stated that more than $78.6 \%$ of the farmers raised their pigs in the backyard of their own homes, where they also grew fruit trees, vegetables, and herbs. All the farms (100\%) raised crossbred pigs i.e., mixed breeds, and also kept other farm animals such as cows, horses, chickens, ducks, dogs, cats, birds, and even rodents such as guinea pigs. All the farmers stated that they raised pigs for the family's own consumption, although there was also one farm that sold or exchanged the animals (Table 3).

About $92.9 \%$ of the farms had pig pens with cement floors, and $64.3 \%$ of them were covered with fiber cement roof tiles. Some farmers also allowed their pigs to roam freely around the houses during part of the day. As for animal handling, $100 \%$ of the farmers reported providing drinking water for their pigs, wheat bran in their feed, and human food leftovers that were previously stored in plastic drums. The farmers also stated that they did not adopt the practice of sanitary

Table 1. Parasites detected in fecal and ear skin scraping samples from pigs raised on different family farms located in Tanguá city, state of Rio de Janeiro, Brazil

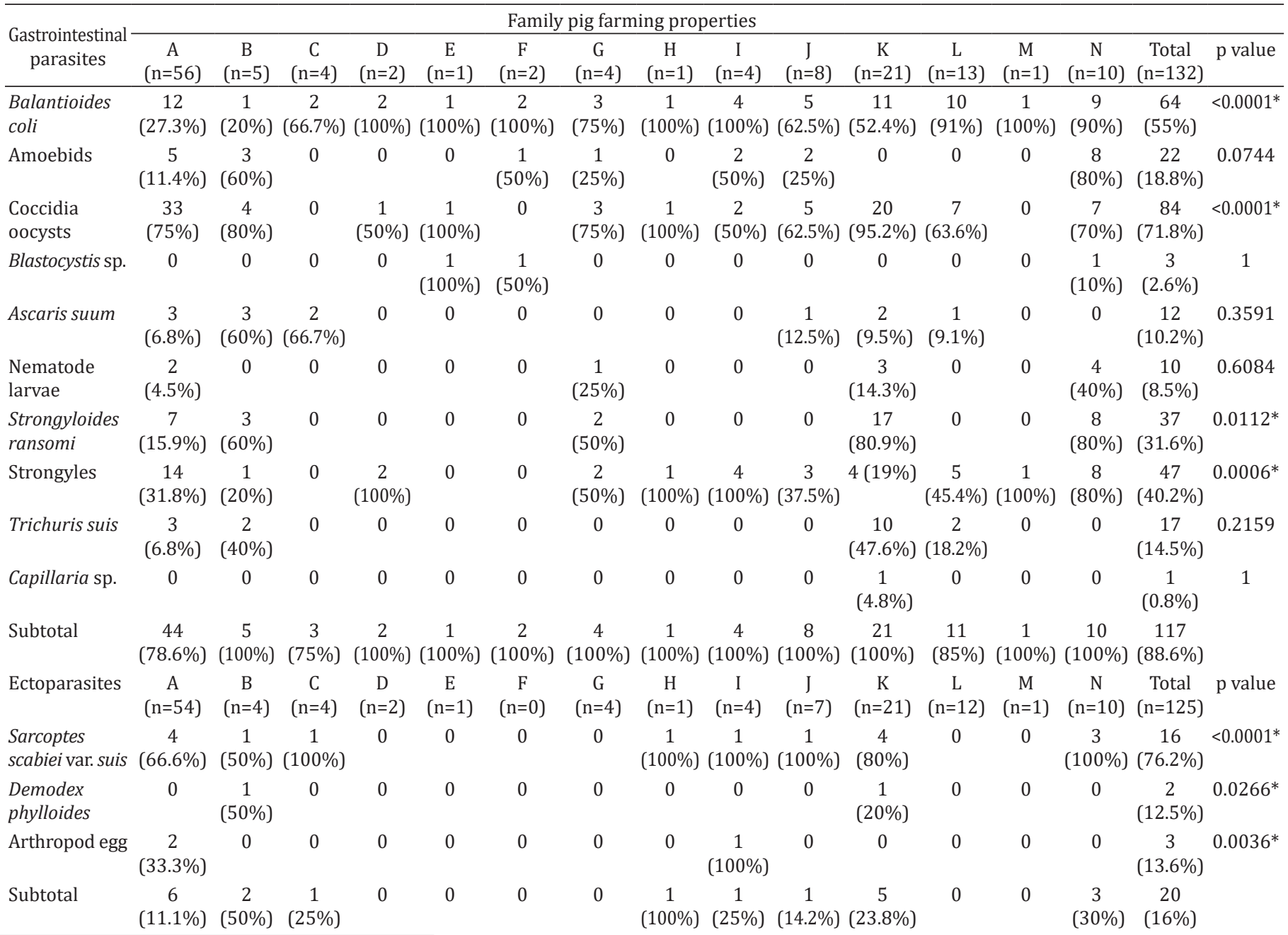

${ }^{*}$ p value $<0.05$. 
breaks, and not use a flamethrower to disinfect the pig pens. Most of the farmers, i.e., $85.7 \%$, reported pouring water over the animals to cool them (Table 3).

Based on the forms, the technical visits, and especially the "field day" activity, it was found that more than $75 \%$ of the farmers fed and watered the pigs directly in cement troughs built on the floor of the pens. During the field activities, the team members noticed accumulated excreta in many of the pig pens. Most of the farmers also reported that they had already seen pigs scratching themselves, had never found blood in the pigs' feces, and vaccinated and wormed their animals. They reported that they did not treat their pigs with anti-ectoparasitic drugs, and that they had seen rats on the farm. They reported that they washed the pens with water, and used brooms and shovels only to muck out the enclosures. Half of the farmers stated that they wore the clothes the entire day, and did not wear them solely when handling the pigs (Table 3).

Of the 42 participants in this study, i.e., the farmers and their family members, 36 delivered stool samples. Seven of these 36 stool samples, $7 / 36$ (19.4\%), contained evolutionary forms of parasites, including Entamoeba coli cysts in 4/36 (19.4\%), which were identified in stool samples from four individuals from farms A, B, I and N. In addition, Ascaris lumbricoides eggs were found in 3/36 (8.3\%) stool samples from two people on farm I, and from one person on farm J, as well as Trichuris trichiura eggs in the stool of two individuals, $2 / 36$ (5.5\%), one from farm B and the other from farm J.

The information provided by the farmers and their families who delivered the fecal samples revealed that more than $80 \%$ of them had never noticed fragments of helminths in their stool or blood, and had already had stool tests and taken antiparasitic medicine. About $61.1 \%$ of the participants stated they felt no intestinal pain and $69.4 \%$ had not suffered from diarrhea in the previous six months. The majority (58.3\%) stated that they wash roots and leafy vegetables in water and vinegar, and 55.5\% stated they use tap water from the public water supply system and artesian well for drinking and cooking. About half of the farms who delivered the stool samples (52.3\%) use filters to treat their drinking water (Table 4).

All the farmers participated in the extension activities carried out on the farms. The 3 rd technical visit was particularly relevant, since this was when the lab test results of the pigs and humans were delivered and the interactive lecture "Parasites and the importance of their control" was given. The participants demonstrated their interest by asking numerous questions about the lab test results, parasite transmission routes, and possible treatments and preventive measures.

On the 4 th visit, all the farmers participated in the proposed "field day" activities with the team. The team interacted with them as they cleaned the pig pens, suggesting changes in some routine practices that might be harmful to the animals' health. The following suggestions stand out: remove dry feces from the pens (mucking out), especially on rainy and cold days, and avoid cleaning your home with the same cleaning supplies used in pig pens. Another important point is to remember to wash out the feed and water troughs regularly and provide fresh clean water ad libitum. Provide straw bedding for farrowing sows close to parturition and newborn piglets. Try to use natural resources available on the farm to feed the pigs, such as frugivorous plants and leaves such as banana, Eucalyptus and kingwood (Astronium fraxinifolium).

During the 5 th, 6 th and 7 th visits to each farm, the researchers observed that the farmers and their families were adopting strategies the team had suggested, such as

Table 2. Frequency of parasites detected in fecal and ear skin scraping samples from pigs, according to sex and age group, raised on family farms in Tanguá city, state of Rio de Janeiro, Brazil

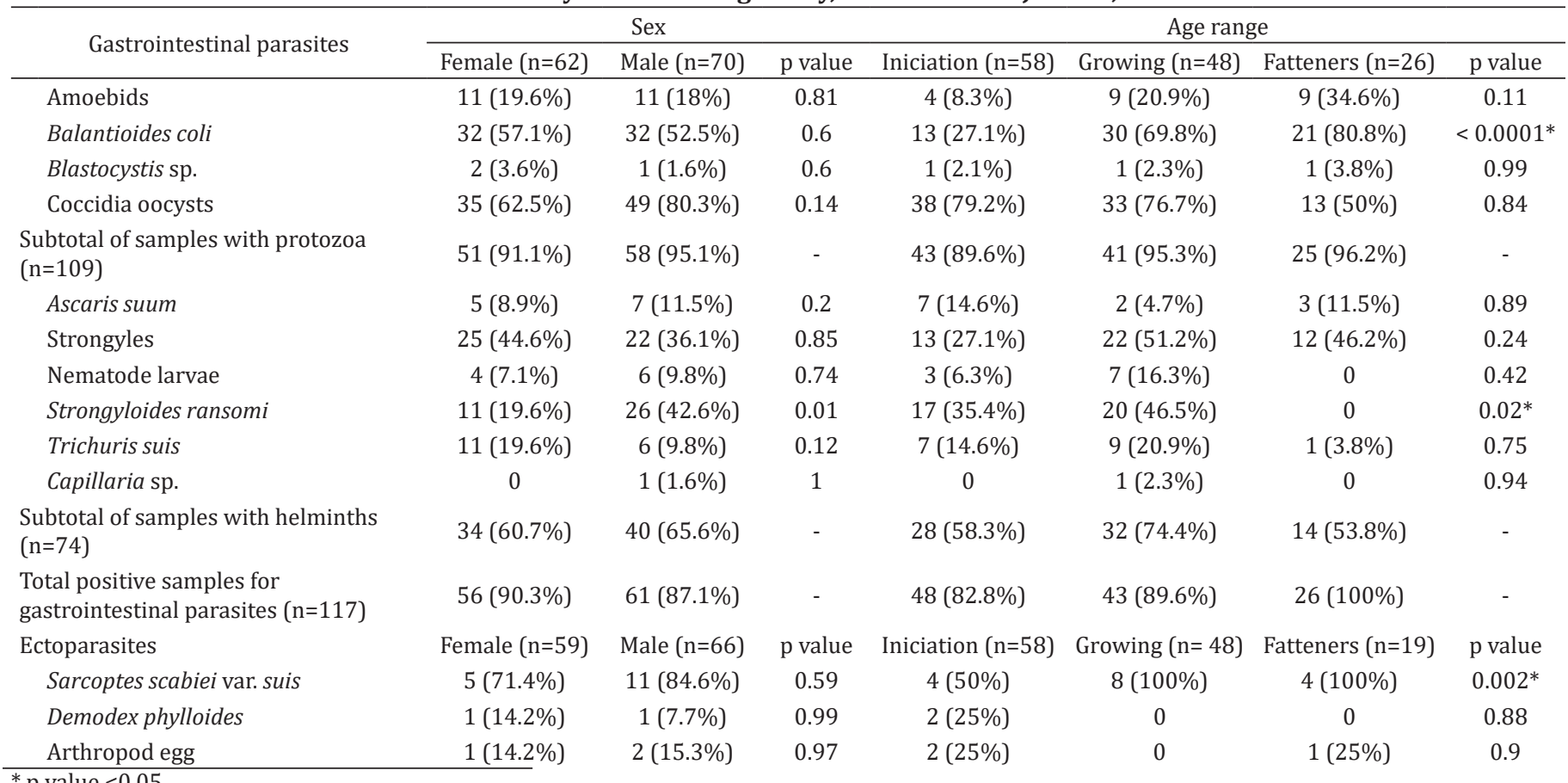


Table 3. Social, economic and pig management information garnered from the questionnaires pertaining to the 14 family pig farms, located in Tanguá city, state of Rio de Janeiro, Brazil

\begin{tabular}{|c|c|c|c|c|c|c|}
\hline \multirow{2}{*}{ Information } & \multicolumn{6}{|c|}{ Responses in order of frequency } \\
\hline & 1st place & Farms $(\%)$ & 2nd place & Farms (\%) & 3rd place & Farms $(\%)$ \\
\hline Property type & Backyard of the homes & 78.6 & Little farm & 21.4 & - & 0 \\
\hline $\begin{array}{l}\text { Grew fruit trees, } \\
\text { vegetables, and herbs }\end{array}$ & Yes & 92.9 & No & 7.1 & - & 0 \\
\hline Breed of the pig & Mixed breeds & 100 & - & 0 & - & 0 \\
\hline Purpose of breeding & Consumption and sale & 57.1 & Consumption and exchange & 28.6 & Consumption & 14.3 \\
\hline Pig reproduction & No & 64.3 & Hand Mating & 35.7 & - & 0 \\
\hline $\begin{array}{l}\text { Care of piglets born on } \\
\text { your property }\end{array}$ & $\begin{array}{c}\text { Teeth cutting. iron } \\
\text { shot and anti-parasitic } \\
\text { medicine }\end{array}$ & 50 & Doesn't do anytihing & 35.7 & $\begin{array}{l}\text { Teeth cutting. iron shot e } \\
\text { breast-feeding after born }\end{array}$ & 14.3 \\
\hline Type of housing for pigs & Pen & 78.6 & $\begin{array}{l}\text { Pen and free pigs in the } \\
\text { vicinity of the house }\end{array}$ & 21.4 & - & 0 \\
\hline Facilities type & Pen with mansory walls & 85.7 & Pen with wood fence wall & 14.3 & - & 0 \\
\hline Floor pen & Cemented & 92.9 & Dirt floor & 7.1 & - & 0 \\
\hline Roof pen & $\begin{array}{l}\text { Fully covered with fiber } \\
\text { cement roof tile }\end{array}$ & 64.3 & $\begin{array}{l}\text { Partially covered with fiber } \\
\text { cement roof tile or french } \\
\text { roof tile }\end{array}$ & 28.6 & Without roof & 7.1 \\
\hline Water to cool the pig & $\begin{array}{l}\text { Play on the animal's body } \\
\text { with a hose or bucket }\end{array}$ & 85.7 & $\begin{array}{l}\text { Water slide on the floor } \\
\text { like a little pool }\end{array}$ & 14.3 & - & 0 \\
\hline $\begin{array}{l}\text { Supply of drinking } \\
\text { water }\end{array}$ & Once or twice a day & 71.4 & Three times or more a day & 28.6 & - & 0 \\
\hline $\begin{array}{l}\text { Type of drinking } \\
\text { fountains }\end{array}$ & $\begin{array}{l}\text { Cement container attached } \\
\text { to the floor }\end{array}$ & 78.6 & $\begin{array}{l}\text { Cement sink attached on } \\
\text { the floor }\end{array}$ & 21.4 & - & 0 \\
\hline $\begin{array}{l}\text { Food provided to } \\
\text { animals }\end{array}$ & $\begin{array}{l}\text { Wheat bran, cornmeal, } \\
\text { food remnants from } \\
\text { producers and commercial } \\
\text { establishments }\end{array}$ & 57.1 & $\begin{array}{l}\text { Wheat bran and food } \\
\text { remnants of the producers }\end{array}$ & 28.6 & $\begin{array}{l}\text { Wheat bran. granulated } \\
\text { wheat, food remnants } \\
\text { from producers } \\
\text { and commercial } \\
\text { establishments }\end{array}$ & 14.3 \\
\hline Feeder type & $\begin{array}{l}\text { Cement container attached } \\
\text { to the floor }\end{array}$ & 92.9 & Wooden container & 7.1 & - & 0 \\
\hline Food storage location & Plastic drum type & 85.7 & $\begin{array}{l}\text { Bathtub with lid or does } \\
\text { not store }\end{array}$ & 14.3 & - & 0 \\
\hline $\begin{array}{l}\text { Other animals in the } \\
\text { farms }\end{array}$ & Yes & 100 & No & 0 & - & 0 \\
\hline $\begin{array}{l}\text { Observed rats on the } \\
\text { property }\end{array}$ & Yes & 64.3 & No & 35.7 & - & 0 \\
\hline Observed the pigs itch & Yes & 50 & No & 50 & - & 0 \\
\hline $\begin{array}{l}\text { Noted blood on the pig } \\
\text { feces }\end{array}$ & No & 85.7 & Yes & 14.3 & - & 0 \\
\hline Vaccinated animals & $\begin{array}{l}\text { Yes. association with any } \\
\text { injection }\end{array}$ & 78.6 & No & 21.4 & - & 0 \\
\hline Anti - parasitc medicine & Yes. worm medicine & 85.7 & $\begin{array}{l}\text { Yes. medicine made with } \\
\text { plant or iron shot }\end{array}$ & 14.3 & - & 0 \\
\hline $\begin{array}{l}\text { Annti - ectoparasitic } \\
\text { medicine }\end{array}$ & No & 71.4 & $\begin{array}{l}\text { Yes. cresol-based } \\
\text { disinfectant }\end{array}$ & 28.6 & - & 0 \\
\hline $\begin{array}{l}\text { Accumulation of excreta } \\
\text { in the pig enclosure } \\
\text { (team observation) }\end{array}$ & Yes & 64.3 & No & 35.7 & - & 0 \\
\hline Cleaning the enclosures & $\begin{array}{c}\text { Removal of feces manually } \\
\text { dry and with water, } \\
\text { brooms and shovels }\end{array}$ & 57.1 & $\begin{array}{l}\text { Removal of feces with } \\
\text { water }\end{array}$ & 42.9 & - & 0 \\
\hline Sanitary break & No & 100 & - & - & - & 0 \\
\hline $\begin{array}{l}\text { Use of the flamethrower } \\
\text { like to fire broom }\end{array}$ & No & 100 & - & - & - & 0 \\
\hline $\begin{array}{l}\text { Cleaning utensils } \\
\text { intended only for } \\
\text { cleaning the pig facility }\end{array}$ & Yes & 85.7 & No & 14.3 & - & 0 \\
\hline Specific clothing only & Yes & 50 & - & 0 & - & 0 \\
\hline for handling pigs & No & 50 & - & 0 & - & 0 \\
\hline
\end{tabular}


Table 4 . Social and health information garnered from the questionnaires answered by the 36 study participants, pig farmers and their families, in Tanguá city, Rio de Janeiro, Brazil

\begin{tabular}{|c|c|c|c|c|c|c|c|c|}
\hline \multirow[b]{2}{*}{ Information } & \multicolumn{8}{|c|}{ Responses in order of frequency } \\
\hline & 1st palce & $\begin{array}{c}\text { Delivered } \\
\text { the stool }(\%)\end{array}$ & 2nd place & $\begin{array}{c}\text { Delivered the } \\
\text { stool }(\%)\end{array}$ & 3rd place & $\begin{array}{c}\text { Delivered the } \\
\text { stool }(\%)\end{array}$ & 4th place & $\begin{array}{c}\text { Delivered the } \\
\text { stool }(\%)\end{array}$ \\
\hline $\begin{array}{l}\text { Performed stool } \\
\text { examination }\end{array}$ & Yes & 88.8 & No & 11.1 & - & 0 & - & 0 \\
\hline $\begin{array}{l}\text { Anti - parasitic } \\
\text { medicine }\end{array}$ & Yes & 83.3 & No & 16.7 & - & 0 & - & 0 \\
\hline Intestinal pain & No & 61.1 & Yes & 38.8 & - & 0 & - & 0 \\
\hline $\begin{array}{l}\text { Diarrhea in the last } \\
\text { six months }\end{array}$ & No & 69.4 & Yes & 30.5 & - & 0 & - & 0 \\
\hline $\begin{array}{l}\text { Pieces of helminth } \\
\text { or whole helminth in } \\
\text { their feces }\end{array}$ & No & 88.9 & Yes & 11.1 & - & 0 & - & 0 \\
\hline $\begin{array}{l}\text { Observed blood in } \\
\text { his stool }\end{array}$ & No & 97.2 & Yes & 2.7 & - & 0 & - & 0 \\
\hline $\begin{array}{l}\text { Residence water } \\
\text { supply }\end{array}$ & $\begin{array}{c}\text { Public piped } \\
\text { water and artesian } \\
\text { well }\end{array}$ & 55.5 & $\begin{array}{l}\text { Artesian } \\
\text { well }\end{array}$ & 19.4 & $\begin{array}{l}\text { Public piped } \\
\text { water }\end{array}$ & 19.4 & Spring water & 5.5 \\
\hline Water treatment & Filtered & 52.3 & Untreated & 47.6 & - & 0 & - & 0 \\
\hline \multirow{2}{*}{$\begin{array}{l}\text { Hygiene of roots and } \\
\text { leafy vegetables }\end{array}$} & $\begin{array}{c}\text { Washing with } \\
\text { water and vinegar }\end{array}$ & 58.3 & $\begin{array}{l}\text { Washing } \\
\text { with water }\end{array}$ & 22.2 & $\begin{array}{l}\text { Washing with } \\
\text { water. vinegar } \\
\text { and lemon }\end{array}$ & 5.5 & \multirow{2}{*}{$\begin{array}{c}\text { Washing } \\
\text { vinegar and } \\
\text { bleach water }\end{array}$} & 5.5 \\
\hline & - & - & - & - & $\begin{array}{c}\text { Washing } \\
\text { bleach water }\end{array}$ & 8.3 & & - \\
\hline
\end{tabular}

providing mothers and newborn piglets with straw bedding, mucking out the pens before washing them down, and even improving the animals' facilities, such as building roofs and walls, as well as expanding these facilities.

\section{DISCUSSION}

The voluntary participation of family farmers in Tanguá/RJ and parasitology research enabled the detection of gastrointestinal parasites in $88.6 \%$ of the pig fecal samples, with parasite positivity rates ranging from $75 \%$ to $100 \%$. Positivity rates lower than those in this study were reported in pigs on $66.3 \%$ of family farms located in Fálcon, Venezuela (Perfetti et al. 2013). However, parasite positivity rates higher than those found in this study were reported at family farms located in different municipalities in the state of Rio de Janeiro, such as Itaboraí, Rio Bonito, Silva Jardim, Saquarema, Maricá, Araruama and Casimiro de Abreu, where an overall positivity rate of $93.1 \%$ was recorded, while the Federal District showed a positivity rate of $96.1 \%$ and Sergipe a rate of $90 \%$ (Aguiar 2009, Brito et al. 2012, Barbosa et al. 2015a).

The high parasite positivity rates detected in the feces of pigs on family farms in Tanguá was already expected. Although most of the farmers raised pigs in a confined system, they clearly invested very little in sanitary management. The team's technical visits enabled them to observe heaps of organic matter, mainly excreta, in several pens, which may have favored the maintenance of evolutionary forms of parasites in the environment, and hence, infections. The lack of investments in health management by pig farmers was also revealed in their answers on the questionnaire. None of the family farms reported using a sanitary break, nor sanitizing the pig pens with a flamethrower. In fact, the farmers were unfamiliar with these terms, which had to be explained to them by the team members. D'Alencar et al. (2011) reported that pig pens on small family pig farms in Pernambuco were cleaned once a day using only water jets. This was a practice also found on the family farms in Tanguá. Most farmers stated they washed the pens, as well as feed and water troughs, only with water, without using any chemical product facilitate the removal of organic matter. This practice was also observed during the "field day" extension activity on the 4th technical visit.

In this study, evolutionary forms of protozoa were more commonly identified than those of helminths. A similar situation was reported at family farms in the Federal District and in the state of Rio de Janeiro (Aguiar 2009, Barbosa et al. 2015a). Although most farmers had reportedly already dewormed their animals, these drugs are known to be effective in the elimination of helminths, but ineffective in the control of protozoa, which may have favored the higher incidence of the latter group of parasites. Family farmers in Pernambuco interviewed by D'Alencar et al. (2011) also reported deworming their pigs with anthelmintics, and helminth positivity rates in Pernambuco ranged from $1.7 \%$ to $13.8 \%$, i.e., much lower than those detected in pigs in Tanguá. Although the farmers in this study stated that they treated their animals with anthelmintics, they were not asked how often this treatment was applied. However, it should be noted that although the farmers reported having dewormed their animals, they could not recall the brand name of the drug, the color of the packaging, or the active ingredient it contained. Infrequent deworming, as well as the active ingredient in the antiparasitic drug, may have contributed the high parasite positivity rate, especially of helminths, found in the fecal samples of pigs in Tanguá.

Non-sporulated oocysts of coccidia compatible with the genus Eimeria and with Cystoisospora suis were the most frequently detected evolutionary forms in the animals' feces. Although the presence this parasite was not statistically 
significant as a function of age group, oocysts were mainly found in the fecal matter of the youngest piglets, i.e., in the weaning stage, followed by the growing and fattening stages. On a subsistence farm located in the municipality of Pinheiral, state of Rio de Janeiro, non-sporulated coccidium oocysts were also the parasites most frequently detected in pig feces (Carreiro et al. 2016). The high frequency of coccidia detected in the pigs of this study can be directly attributed to the high resistance of the oocyst in the environment, since it can resist different temperatures and disinfectants, and also due to the large numbers of oocysts released in the feces of infected piglets, i.e., between 1,000 and 400,000 oocysts per gram of feces (Sobestiansky et al. 1999). These factors favor the reinfection of subsequent litters housed on these pig pens, which are not properly sanitized after the piglets are weaned, as evidenced at the family farms of this study.

The second most frequently detected parasite in pig feces was Balantioides coli. This protozoan was found in both female and male pigs, and in all the age groups, but more frequently in the growing and fattening stages. This protozoan is widely reported in parasitology research on pig, including the traditional farms in China studied by Lai et al. (2011), who reported a lower frequency than that found in this study (22.7\%), on family farms analyzed in Venezuela (45.3\%), and among pigs raised in confined and semi-confined systems on the outskirts of Salvador, Bahia, Brazil (46\%) (Pinto et al. 2007, Perfetti et al. 2013). B. coli was the most frequently detected parasite on family farms in Sergipe and in various municipalities in Rio de Janeiro, showing higher positivity rates than that of the present study, i.e., $78 \%$ and 71.6\%, respectively (Brito et al. 2012, Barbosa et al. 2015a).

Pigs are considered the main reservoirs of this parasite, which has a potential for zoonotic transmission (Zaman 1978). It should be noted that the farmers in Tanguá fed wheat bran and leftovers from commercial establishments to their pigs. Wheat is known to be highly rich in carbohydrates, and this nutrient, according to Zaman (1978), Schuster \& Ramirez-Ávila (2008), and Barbosa et al. (2015b, 2018), is the main source of energy for B. coli, and is essential for its development, even in vitro. Thus, the wheat-based feed that was supplied to the pigs, especially in the fattening stage, may have favored the high positivity rates of this protozoan, particularly in the growing and fattening age groups.

Despite evidence of high positivity rates of $B$. coli in pigs, the evolutionary forms of this protozoan have not been detected in humans. High levels of $B$. coli in fecal samples from pigs and negative findings in their producers have also been reported on family farms in Rio Janeiro, as well as in rural communities in Venezuela (Guzmán et al. 2013, Barbosa et al. 2016). Unlike this study, in rural areas of Bolivia, B. coli was detected in stool samples from children and adolescents and in fecal samples from pigs roaming freely in the region (Esteban et al. 1998). It is worth mentioning that none of the farmers and their family members participating in this study reported they had ever detected blood in their stool. Blood is usually a visible element in symptomatic infections by $B$. coli, with dysentery and mucous and bloody diarrhea stools one of the most commonly reported symptoms. The marked presence of evolutionary forms of $B$. coli in the fecal samples from the animals in this study, and their absence in the stool tests of their owners and family members, may be directly related to the personal hygiene and sanitary habits of these individuals, which reduced their exposure to the infectious form of the parasite. It is possible that the low prevalence of balantidiasis in humans could also be explained by antigenic differences, i.e., humans would naturally be resistant to infection by B. coli, even when living in close proximity to parasitized pigs (Walzer et al. 1973). However, this theory has never been proven.

Amoeboids and Blastocystis sp. were also detected in the pigs' feces. The evolutionary forms of these parasites were not studied in depth using parasitological staining techniques. However, it was found that amoeboid cysts generally had only one nucleus and their size was comparable to that of Entamoeba polecki and Entamoeba suis, with a length of $\overline{\mathrm{x}}=13.74 \mu \mathrm{m}( \pm 1.8 \mu \mathrm{m})$ and a width of $\overline{\mathrm{x}}=13.21 \mu \mathrm{m}( \pm 1.9 \mu \mathrm{m})$. Despite the relevant difference between E. polecki and E. suis, since only the former species has so far been reported infecting humans, they could not be differentiated in this study because no molecular techniques were used (Stensvold et al. 2010). In addition to these amoeboids, uninucleated cysts were also detected in five pig fecal samples, showing a morphology compatible with immature cysts of the Entamoeba histolytica/ Entamoeba dispar/Entamoeba moshkovskii complex, $\overline{\mathrm{x}}=22.72 \mu \mathrm{m}$ long $( \pm 4.3)$ and $\bar{x}=21.14 \mu \mathrm{m}( \pm 2.6)$ wide. Like the findings of this study, uninucleated amoeboid cysts were also found in pig feces on family farms located in other municipalities in the state of Rio de Janeiro, albeit with a higher frequency (44\%) than that of this study (Barbosa et al. 2015a). It should be noted that E. polecki, the E. histolytica/E. dispar/E. moshkovskii complex, and Blastocystis spp. are protozoa with zoonotic potential and are therefore transmissible to humans. Furthermore, with the exception of E. polecki, it is not known whether these protozoa can produce symptomatic infections in pigs, which underscores the need for further study with of protozoa. Despite their zoonotic potential, such evolutionary forms were not identified in the stool samples from the human participants of this study, in which only amoeboid cysts with more than five nuclei compatible with $E$. coli were identified.

As for helminths, only nematodes were detected, the most prevalent of which were strongyles, whose eggs were found in all the animals' age groups. Strongyle eggs were considered nematode eggs possibly belonging to the superfamilies Strongyloidea and Trichostrongyloidea. The eggs of these superfamilies are identical; hence, differentiating the species taxonomically requires fecal cultures or molecular biology techniques, which were not used in this study. Strongyles eggs were considered those with thin shells, containing an embryonic mass and having an average length of $102.4 \mu \mathrm{m}$ $( \pm 12.4)$ and average width of $59.5 \mu \mathrm{m}( \pm 7.5)$. Lower frequencies than those of this study, i.e., $23.6 \%$ and $10.6 \%$, were reported on family farms in the municipality of Pinheiral/RJ and on traditional farms in China, respectively (Lai et al. 2011, Carreiro et al. 2016). Barbosa et al. (2015a), who analyzed gastrointestinal parasitosis in swine on family farms located in different municipalities of the state of Rio de Janeiro, reported a positivity rate similar to that found in this study (46.6\%). According to Roepstorff \& Nansen (1996), it should be emphasized that strongyles, particularly Hyostrongylus rubidus and Oesophagostomum spp., are highly relevant in pig farming, since they can cause "thin sow syndrome." This syndrome develops when 4th stage larvae of the parasite in the stomach and intestinal mucosa leave their hypobiotic 
state in response to the hormonal stimulation of parturition in the host and to climate conditions, developing into adult and pathogenic evolutionary forms precisely in the period when sows are suckling their offspring, i.e., when these animals have higher energy needs.

Nematode larvae and larvae of thin-shelled nematode larvae, $\bar{x}=75 \mu \mathrm{m}( \pm 5)$ long and $\bar{x}=47 \mu \mathrm{m}( \pm 4.8)$ wide, similar to Strongyloides ransomi, were identified in the feces of pigs in the initial and growing stages. The average size of the eggs resembling those of $S$. ransomi was slightly larger than that described in the literature for the Rhabditoidea family. Unfortunately, a search of the literature failed to identify any scientific articles that measure the size of this parasite, and only a very few that discuss the biology of Strongyloides spp. in animals. Even so, the eggs detected here were typical of the species that infects pigs. Note the fecal material was processed in the laboratory immediately after collection, thus minimizing the possibility that it belongs to a strongyle species. Although the fecal samples were processed in the laboratory as quickly as possible on the same day they were collected, the fecal samples from pigs that contained eggs typical of $S$. ransomi also contained nematode larvae, which may have hatched from $S$. ransomi eggs. Strongyloidiasis is a parasitic disease that affects mainly young piglets, and may cause them to suffer from severe catarrhal enteritis. It should be noted that sows are the main source of infection for their offspring, and that the parasite is transmitted via percutaneous, oral and transmammary routes (Nansen \& Roepstorff 1999, Sobestiansky et al. 1999). The presence of evolutionary forms of this parasite in piglet feces, especially in the initial stage, on family farms in Tanguá, confirms the parasite is transmitted by infected sows.

Evolutionary forms of Ascaris suum and Trichuris suis were identified in pig feces in all the age groups and in both sexes. These nematodes are extremely important in pig farming because they reduce weight gains, particularly in the fattening stage. In the case of the family farms in Tanguá, would be inserted in the period of growth and fatteners, since the prepatent period of these nematodes varies by about 8 weeks, according to Roepstorff \& Nansen (1996). Moreover, slaughterhouses may discard pig livers due to milk spots, a pathology characteristic of larval migrations in the liver tissue (Bordin 1987). However, pig livers are rarely discarded on family farms, where most of these animals are slaughtered and inspections are not carried out.

Like the family farms in Tanguá, evolutionary forms of A. suum, T. suis and S. ransomi have also been identified in Venezuela, A. suum and T. suis on family farms in Rio de Janeiro, Sergipe, and China, and S. ransomi on industrial farms in Rio de Janeiro (Lai et al. 2011, Brito et al. 2012, Perfetti et al. 2013, Barbosa et al. 2015a, Carreiro et al. 2016). The helminths identified in this study as strongyles, $A$. suum, T. suis and $S$. ransomi, are geohelminths, i.e., helminths that are transmitted primarily through contaminated soil, where they develop the infective structure, which may be 3rd stage nematode larvae (L3) or embryonated eggs. The floors of pigpens on the family farms in Tanguá/RJ, are made of a very thin layer of cement, and most of them were cracked and worn, thus facilitating the accumulation of organic matter. In addition, it was found that most of the water and feed troughs were made of cement built into the floor. This type of trough easily becomes contaminated the animal excreta. Hence, the type of construction of the animals' enclosures on the family farms in Tanguá seems to have favored the development and persistence of the infective stages of parasites, especially of geohelminths.

In addition to these parasites, the identification of eggs typical of Capillaria spp. in pig feces on farm $\mathrm{K}$ was a significant finding, since this nematode does not usually infect pigs. The pigs on this farm may have been ingested Capillaria spp. eggs from the feces of other animals or from the predation of synanthropic animals such as rodents, indicating a possible case of pseudoparasitism. The family farmers in Tanguá reported the sporadic appearance of rats on their farms. It should be kept in mind that pigs are omnivores and may prey on these rodents if they enter their pens. Synanthropic rodents such as rats may be carriers of a variety of infectious agents that are harmful to animal health. This sanitary problem was discussed with the farmers during the fieldwork. The presence of rodents on pig farms does not seem to be a problem solely of family farms in Brazil, since it also occurs in intensive pig farming in France, according to Beloeil et al. (2003).

The presence of rodents in herds in the municipality of Tanguá may be attributed to the practice of storing pig feed, as the farmers themselves reported. The practice of feeding leftovers to pigs was also reported by Rocha et al. (2016), who analyzed 67 farms in Senador Canedo, Goiás based on socioeconomic, zootechnical and environmental questionnaires. Another important point is the fact that the financial status of most of the pig farmers in this study is precarious. This means that commercial pig feed is too expensive for most farmers, who feed their pigs leftovers of human food, knowing that pigs readily consume leftovers and are omnivorous, like humans.

Sixteen percent of the ear skin scrapings from pigs on the family farms of Tanguá showed evolutionary forms of ectoparasites compatible with Sarcoptes scabiei variety suis, arthropod eggs and Demodex phylloides. S. scabiei var. suis infestation rates in pigs lower than and similar to that of this study were reported in industrial farms in Paraná (0.09\%) and in Goiás (12.1\%), respectively (Oliveira et al. 2006, Silva et al. 2002). Unlike the case records in Tanguá, Sobestiansky et al. (2005) reported a high infestation rate $(43 \%)$ on an industrial farm in Goiás, which already had a previous history of scabies.

Apart from detecting these mites by parasitological techniques, on several occasions during their technical visits the researchers saw pigs rubbing their bodies against the walls of pig pens, trees and against other individuals in the pens, a behavior suggestive of itching caused by scabies. Some of the farmers also described this behavior in their answers to the questionnaire. The infestation rate of evolutionary forms of S. scabiei var. suis might have been even higher if the skin of the ear had been scraped to a greater intradermal depth, where most mites burrow, or if biological material had also been collected from other parts of the pigs' bodies. According to Sobestiansky et al. (2005), scabies can pose problems in pig farming by lowering production rates because mite infested pigs reduce their feed intake, thus slowing down their growth and weight gains. Other evolutionary forms of arthropods were detected in this study, such as eggs characteristic of arthropods that could be $S$. scabiei var. suis, in addition to $D$. phylloides, a mite considered a commensal on the skin of pigs and unharmful to their health. 
Evolutionary forms of parasites, mostly of E. coli, were also detected in the stool samples of the farmers and their family members that participated in this study. This protozoan is not pathogenic, but it can be considered a bioindicator of fecal contamination. In addition to $E$. coli, the geohelminths Ascaris lumbricoides and Trichuris trichiura were also found in the stool of these participants. This finding was expected, since most of the people on these farms worked on the land, cultivating fruit trees, vegetables, and herbs for their own consumption and for sale. The researchers noticed that the children on the farms went barefoot, roaming around all over the place. An important fact that the participants reported at various times during the fieldwork was the lack of basic sanitation in the municipality. They reported that sewage was not treated and that they suspected the public water supply, which was used occasionally, was also untreated. For this reason, the farms sought alternative water sources that are not subject to sanitary monitoring, such as wells and natural springs. In addition to possible infections transmitted through contaminated soil, environment and water, the way in which the participants washed their vegetables and fruits may also have contributed to their ingestion of parasites, since most of them stated they used vinegar incorrectly for this purpose.

In addition to the parasitological evaluation of biological samples from pigs and human participants, extension activities were carried out to transmit information and provide technical support to these small farmers. Unfortunately, extension activities are still undervalued and rarely carried out in Brazil. Therefore, no articles about this theme in national pig farming were found in the literature, indicating that this is a pioneering study.

Even though this information was imparted using simple language in informal conversations, the researchers found that people sometimes found it difficult to understand. Although the participants' educational level was not included in the questionnaire in order to avoid embarrassment, many participants proved to be illiterate when it came time to sign the informed consent form. This may have be why they found it difficult to understand some of the information and/or questions on the forms. During the interactive lecture, the use of visual images clearly facilitated the transmission of information. Moreover, the intervention activity carried out on the field day was also apparently more effective in transmitting information, as it was imparted dynamically while the farmer was mucking out the pig pens. To remind the participants of the most relevant points explained during the technical visits, a poster visually illustrating this information, as well as a calendar, were posted on each farm to encourage and remind the farmers to deworm their animals according to schedule.

In the remaining technical visits to the farms, the researchers checked to ascertain if their instructions were being followed. They found that this was being done properly, such as mucking out the pens regularly and building roofs over pens lacking protection from weather. Over the course of the various visits, a relationship of mutual trust was established between the farmers and their families and the research team. This relationship was further reinforced through the continuing contact of the farmers with the researchers to ask for technical support, even after the study was concluded. The primary focus of this study was parasitological research allied to extension activities carried out in seven technical visits to impart information for improved sanitary management in raising pigs, thereby improving the economic status of small farmers. However, it is impossible to predict whether or not the information imparted to these farmers will be lost over time. In view of this real possibility, it would be ideal for small farmers to be given permanent technical support.

\section{CONCLUSIONS}

The high parasite positivity rates found in the fecal samples from pigs in the municipality of Tanguá appear to be directly attributable to the ineffective health management these farmers give their animals, as was revealed in the forms and observed by the researchers during their technical visits to the farms. In addition, evolutionary forms of parasites were also detected in the stool samples of farmers and their family members. This situation may be the result of poor sanitation in the municipality, according to reports by the participants of this study, as well as inadequate hygiene habits, according to information retrieved from the questionnaires.

The overall situation underscores the need for publicly sponsored programs to provide technical and financial aid for these small farmers. In the case of the family farms in the municipality of Tanguá, these farmers raise pigs as a means of subsistence, since they all eat pork and some of them reported that the sale and/or exchange of pigs for other products was a second source of family income. Silva Filha et al. (2011) stated that for these breeders, owning these animals represents not only a source of income but in many cases is also a family tradition. However, this study clearly revealed the farmers' precarious financial status and inadequate technical conditions to raise their animals properly, as well as their lack of access to and/or understanding of what constitutes proper hygienic habits.

Acknowledgements.- The authors would like to thank for project support: Proex (Dean's Office of extension of "Universidade Federal Fluminense") and to family producers in Tanguá, Rio de Janeiro, who participated in this study.

Conflict of interest statement.- The authors declare that they have no conflict of interest.

\section{REFERENCES}

Aguiar P.C. 2009. Aspectos epidemiológicos das parasitoses gastrintestinais de suínos naturalizados de criações familiares do Distrito Federal. Doctoral Dissertation, Universidade de Brasília, Brasília.

Barbosa A.S., Bastos O.M.P., Dib L.V., Siqueira M.P., Cardozo M.L., Ferreira L.C., Chavez W.T., Fonseca A.B.M., Uchôa C.M.A. \& Amendoeira M.R.R. 2015a. Gastrointestinal parasites of swine raised in different management systems in the State of Rio de Janeiro, Brazil. Pesq. Vet. Bras. 35(12):941-946. <https://dx.doi.org/101590/S0100-736X2015001200001>

Barbosa A.S., Bastos O.M.P., Uchôa C.M.A., Dib L.V. \& Amendoeira M.R.R. 2016. Avaliação da frequência de Balantidium coli em suínos, tratadores de suínos e primatas não humanos no estado do Rio de Janeiro. Revta Patol. Trop. 45(3):285-293. <https://dx.doi.org/10.5216/rpt.v45i3.43505>

Barbosa A.S., Bastos O.M.P., Uchôa C.M.A., Pissinatti A., Ferreira Filho P.R., Dib L.V., Azevedo E.P., de Siqueira M.P., Cardozo M.L. \& Amendoeira M.R. 2015 b. Isolation and maintenance of Balantidium coli (Malmsteim, 1857) cultured from fecal samples of pigs and non-human primates. Vet. Parasitol. 210(3/4):240-245. <https://dx.doi.org/10.1016/j.vetpar.2015.03.030> <Pmid:25920329>

Barbosa A.S., Cardozo M.L., Dib L.V., Fonseca A.B.M., Uchôa C.M.A., Bastos O.M.P. \& Amendoeira MRR. 2018. Comparative study of three xenic media 
culture for cultivation of Balantidium coli strains. Revta Bras. Parasitol. Vet. 27(1):19-25. <https://dx.doi.org/10 1590/s1984-29612017075>

Beloeil P.A., Chauvin C., Fablet C., Jolly J.P., Eveno E., Madec F. \& Reperant J.M. 2003. Helminth control practices and infections in growing pigs in France. Livest. Product. Sci. 81(1):99-104.<https://dx.doi.org/10.1016/ S0301-6226(02)00192-6>

Bordin E.L. 1987. Relações entre infecções por parasitas internos de suínos e o custo de alimentação: uma revisão. Hora Vet. 7(39):21-27.

Brasil 2015. Lei no 0971 de 24 de junho de 2015 - Aprova o plano municipal de educação para o decênio 2015-2025 e dá outras providências. Avalaible at <https://www mprj mp br/documents/20184/203908/Tangua5 pdf> Accessed on Mar. 30, 2019.

Brito G.G., Santos T.B., Melo C.M., Jeraldo V.L.S. 2012. Ocorrência de enteroparasitas em amostras fecais de suínos do município de Simão Dias, SE. Ciênc. Biol. Saúde 1(15):11-18.

Carreiro C., Coelho C.D., Jorge J.L.B.P. \& Costa N.O.G., Paiva R.V., Filho Teixeira W.L., Rosa A.G. \& Jesus V.L.T. 2016. Parasitos intestinais em suínos confinados em uma criação no município de Pinheiral, RJ. Revta Bras. Med. Vet. 38(supl.2):117-122.

D’Alencar A.S., Farias M.P.O., Rosas E.O., Lima M.M., Alves L.C. \& Faustino M.A.G. 2011. Influência do manejo higiênico-sanitário na infecção por helmintos gastrintestinais em suínos de granjas tecnificadas e de subsistência abatidos na Região Metropolitana de Recife e Zona da Mata do Estado de Pernambuco, Brasil. Arqs Inst. Biológico, São Paulo, 78(2):207-215.

Embrapa 2018. Qualidade da carne suína. Avalaible at <https://www. embrapa.br/qualidade-da-carne/carne-suina>. Accessed on Oct. 30, 2018.

Esteban J.G., Aguirre C., Angles R., Ash L.R. \& Mas-Coma S. 1998. Balantidiasis in Aymara children from northern Bolivian altiplano. Am. J. Trop. Med. Hyg. 59(6):922-927. <https://dx.doi.org/10.4269/ajtmh.1998.59.922> <PMid:9886201>

Faust E.C., D’Antoni J.S., Odon V., Miller M.J., Perez C., Sawitz W., Thomen L.F., Tobie J.E. \& Walker J.H. 1938. A critical study of clinical laboratory technics for the diagnosis of protozoan cysts and helminth eggs in feces I Preliminary communication. Am. J. Trop. Med. 18(4):169-183. <https:// dx.doi.org/10.4269/ajtmh.1938.s1-18.169>

Ferreira S.C.T. 2010. Contribuição para o estudo de sarna sarcóptica em suínos abatidos para consumo. Master's Thesis, Universidade de Trás-os-Montes e Alto Douro, Vila Real.

Guzmán C.R., Nessi A.P., Gonzáles O.H., Hernández M.O. \& Galindo M. 2013. Balantidium spp. en cerdos y sus criadores: prevalencia em comunidades de dos Estados de Venezuela. Vitae 54:1-10.

Huber F., Bomfim T.C. \& Gomes R.S. 2003. Comparação da eficiência da técnica de sedimentação pelo formaldeído-éter e da técnica de centrífugo flutuação modificada na detecção de cistos de Giardia sp. e oocistos de Cryptosporidium sp. em amostras fecais de bezerros. Revta Bras. Parasitol. Vet. 12(2):135-137.

Lai M., Zhou R.Q., Huang H.C. \& Hu S.J. 2011. Prevalence and risk factors associated with intestinal parasites in pigs in Chongqing, China. Res. Vet. Sci. 91(3):121-124. <https://dx.doi.org/10.1016/j.rvsc.2011.01.025> $<$ PMid:21349561>

Lutz A.O. 1919. Schistosomum mansoni e a Schistosomatose segundo observações, feitas no Brazil. Mem. Inst. Oswaldo Cruz 11(1):121-155. <https://dx.doi.org/10.1590/S0074-02761919000100006>

Nansen P. \& Roepstorff A. 1999. Parasitic helminths of the pig: factors influencing transmission and infection levels. Int. J. Parasitol. 29(6):877891. <https://dx.doi.org/10.1016/S0020-7519(99)00048-X>

Oliveira A.B., Biondo A.W., Alberton G.C., Santis A.P.T., Vianna G.N.O., Teixeira M.A. \& Pieper M. 2006. Prevalência de Sarcoptes scabiei var. suis em granjas de reprodutores suídeos certificadas do estado do Paraná, no período de 2002 a 2004. Arch. Vet. Sci. 11(2):61-65. <https://dx.doi.org/10.5380/ avs.v11i2.6801>

Pedroso-de-Paiva D., Móres N., Barioni Júnior W., Costa O.A.D., Sobestianski J. \& Amaral A.L. 2003. Fatores de risco associados à ocorrência de sarna sarcóptica e prevalência em suínos nas fases de crescimento e terminação, na região sul do Brasil. Ciência Rural 33(4):731-736. <https://dx.doi. org/10.1590/S0103-84782003000400023>

Perfetti D.J.C., Quintero M.E.A., Low J.L.T. \& Moreno P.M. 2013. Prevalencia de enteroparásitos porcinos en una comunidad rural de la península de Paraguaná, Estado Falcón, Venezuela. Revta Cient. Facultad Ciencias Veterinarias, Zulia, 23(1):19-25. <https://www researchgate net/ publication/288575568>

Pinto J.M.S., Costa J.O. \& Souza J.C.A. 2007. Ocorrência de endoparasitos em suínos criados em Itabuna, Bahia, Brasil. Ciênc. Vet. Trop. 10(2/3):79-85.

Ritchie L.S. 1948. An ether sedimentation technique for routine stool examinations. Bull. US Army Med. Depart. 8(4):326. <PMid:18911509>

Rocha L.O., Oliveira R.M., Hellmeister Filho P., Gomes N.A., Carneiro M.F., Silva O.M \& Fernandes L.C. 2016. Diagnóstico Participativo/Rural aplicado à criação de aves e suínos caipiras em regiões periurbanas no município de Senador Canedo (GO). Fronteiras, J. Social Technol. Environ. Sci. 5(2):135 152. <https://dx.doi.org/10.21664/2238-8869.2016v5i2.p135-152>

Roepstorff A. \& Nansen P. 1996. FAO Animal Health Manual: epidemiology, diagnosis and control of helminth parasites of swine. Food and Agricultural Organization of United States Press, Rome.

Roepstorff A., Nilsson O., Oksanen A., Gjerde B., Richter S.H., Örtenberg E., Christensson D., Martinsson K.B., Bartlett P.C., Nansen P., Eriksen L., Helle O., Nikander S. \& Larsen K. 1998. Intestinal parasites in swine in the Nordie countries: prevalence and geographical distribution. Vet. Parasitol. 76(4):305-319.<https://dx.doi.org/10.1016/s0304-4017(97)00223-9> $<$ PMid:9650867>

Schuster F.L. \& Ramirez-Ávila L. 2008. Current world status of Balantidium coli. Clin. Microbiol. Rev. 21(4):626-638. <https://dx.doi.org/10.1128/ CMR.00021-08> <PMid:18854484>

Sheather A.T. 1923. The detection of intestinal protozoa and mange parasites by a floatation technique. J. Comp. Pathol. 36:266-275. <https://dx.doi. org/10.1016/S0368-1742(23)80052-2>

Silva E.V., Sobestiansky J., Linhares G.F.C., Vieira R.C., Oliveira J.P.O. \& Vieira M.C.M. 2002. Prevalência de sarna sarcóptica em suínos mantidos em criações intensivas na microrregião de Goiânia, GO, Brasil. Revta Patol. Trop. 31(2):225-232. <https://dx.doi.org/10.5216/rpt.v31i2.14567>

Silva Filha O.L., Barbosa E.J.R., Lima A.D., Melo A.G.P., Melo Filho A.J. \& Sá MS. 2011. Os produtores de suínos no Município de Floresta, Estado de Pernambuco, Brasil. AICA 1(2011):416-418.

Sobestiansky J., Barcelos J., Mores N., Carvalho L. \& Oliveira S. 1999. Clínica e Patologia Suína. Gráfica Art3, Goiânia. 464p.

Sobestiansky J., Linhares G.F.C., Silva E.V. \& Linhares D. 2005. Aspectos clínicos e epidemiológicos de um foco de sarna sarcóptica em um sistema intensivo de produção de suínos localizado no município de TeresópolisGO, Brasil. Revta Patol. Trop. 34(1):61-67. <https://dx.doi.org/10.5216/ rpt v34i1 2138>

Solaymani-Mohammadi S. \& Petri Jr W.A. 2006. Zoonotic implications of the swine-transmitted protozoal infections. Vet. Parasitol. 140(3/4):189-203 <https://dx.doi.org/10.1016/j.vetpar.2006.05.012> <PMid:16828229>

Stensvold C.R., Lebbad M. \& Clark C.G. 2010. Genetic characterization of uninucleated cyst producing Entamoeba spp. from ruminants. Int. J. Parasitol. 40(7):775-778.<https://dx.doi.org/10.1016/j.ijpara.2010.03.003> $<$ PMid:20359482>

Walzer P.D., Judson F.N., Murphy K.B., Healy G.R., English D.K. \& Schultz M.G. 1973. Balantidiasis outbreak in Truk. Am. J. Trop. Med. Hyg. 22(1):33-41. <https://dx.doi.org/10.4269/ajtmh.1973.22.33><PMid:4684887>

Young K.H., Bullock S.L., Melvin D.M. \& Spruill C.L. 1979. Ethyl acetate as a substitute for diethyl ether in the formalin-ether sedimentation technique. J. Clin. Microbiol. 10(6):852-853.<https://dx.doi.org/10.1128/JCM.10.6.852853.1979><PMid:574877>

Zaman V. 1978. Balantidium coli, p.633-653. In: Kreier J.P. (Ed.), Parasitic Protozoa. Academic Press, New York. 